\title{
4
}

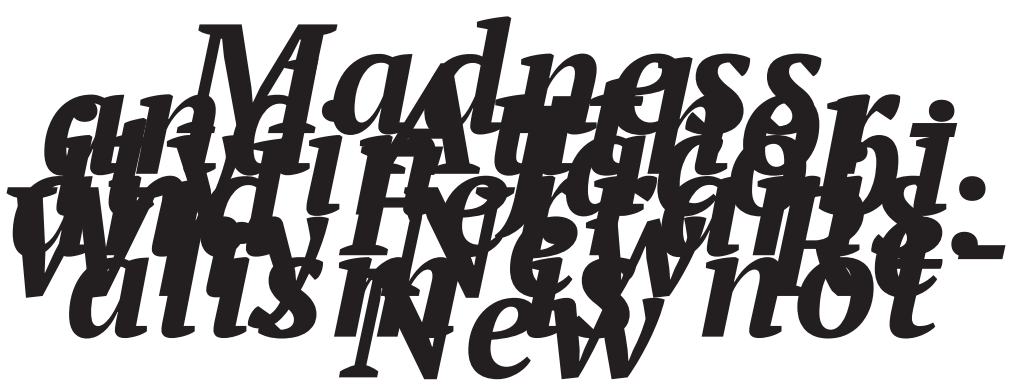

\author{
Benjamin Norris \\ Visiting Researcher, Rhetoric \\ UC Berkeley, \\ 2417 Ashby Ave, Berkeley Ca 94705 \\ E-mail:norrb741@newschool.edu

\section{Madness and Authority in Jacobi and Ferraris: Why New Realism Is Not New ${ }^{1}$}

\begin{abstract}
:
New Realism is not new. Instead of a new response to a novel philosophical problem, New Realism is an unacknowledged resurrection of Jacobi's criticism of philosophical rationality that ignited what is now known as the "pantheism controversy." Both Jacobi and Ferraris argue that the antirealist epistemologies of their contemporaries displace our relation to the world to which

${ }^{1} \mathrm{~A}$ few acknowledgments are in order. I would like to thank the reviewers for their helpful comments. I would like to thank P.J. for suggesting I submit a piece to this issue. I would also like to thank Meg, Ryan, Kelly and the rest of my shelter-in-place support network-Ben, April 10, 2020.
\end{abstract}


thought is supposed to be beholden. Further, both Jacobi and Ferraris claim that the antidote to these delusional philosophical ideations is realism. Finally, both take a reactionary stance toward the renegotiation of authority that stands at the core of the Enlightenment project. If this is indeed the case, then New Realism is a repetition and not an advance. More significantly, despite its own aspirations, New Realism is a reactionary, antiEnlightenment philosophical proposal. In short, Ferraris says

"Goodbye Kant!" too quickly and for old reasons.

\section{Keywords:}

Speculative realism, new realism, M. Ferraris, F.H. Jacobi, I. Kant

\section{$\mathbf{0}$}

Instead of a brand-new response to a novel philosophical problem, New Realism is a repetition of Friedrich Heinrich Jacobi's criticism of philosophical rationality that ignited what is now known as the pantheism controversy in German academia at the close of the eighteenth century. The following assembles an argument for this being the case by looking at the intertwining of philosophical and social issues expressed by both Jacobi and the New Realist Maurizio Ferraris. ${ }^{2}$ Both Jacobi and Ferraris argue that antirealist epistemologies displace our relation to the world to which thought is supposed to be beholden. By inverting this relation, we become convinced that reality actually is as we construct it to be. As Jacobi argues, we take ourselves to be gods capable of creating worlds through thought alone. This assumption is nothing short of madness; it is this

${ }^{2}$ I have decided to focus on Ferraris in the present essay largely due to the historical narrative he provides for his own brand of New Realism. There are numerous similarities between the positive ontologies offered by both Markus Gabriel and Ferraris, but Gabriel articulates his own New Realism in more formal terms. This gives his realism a wider scope as well as a more nuanced diagnosis of the problem of anti-realism. I have previously written critically of Gabriel's (2015) Fields of Sense: A New Realist Ontology (Norris 2015), but I believe the realism therein is much more sophisticated than that of Ferraris. The thought behind my strategy here is that Ferraris' New Realism represents the basement level of accomplishment in the discourse surrounding the return to realism. By this I mean that though it carries on in the spirit of much contemporary realist philosophy, its brute unsophistication and fundamental mischaracterization of Kantian and post-Kantian philosophy can serve as a barometer for other realisms. The hope is that one will be more easily able to evaluate speculative and realist philosophies in the following way: The closer it is to New Realism (as articulated by Ferraris), the less novel it is. 
madness Jacobi fears more than anything else. This fear of madness, this dementophobia, is shared by Ferraris. It is not just this phobia that Ferraris shares with Jacobi; both Jacobi and Ferraris claim that the antidote to these delusional philosophical ideations is realism. Further, their respective characterizations of the real reveals that both take a reactionary stance toward the renegotiation of authority that stands at the core of the Enlightenment project. If this is indeed the case, New Realism is a repetition and not an advance. Further, it is a fundamentally anti-Enlightenment philosophical development; it is pre-Kantian in the worst of possible ways.

This is, in and of itself, perhaps not a problem. Many philosophical developments secure a lineage in the history of philosophy regardless of conscious or unconscious influence. Further, many philosophies claim to be anti- or post-Enlightenment. Why, then, bring New Realism into conversation with Jacobi's self-proclaimed non-philosophy of non-knowledge? What Jacobi adds to the analysis provided by New Realism is that the crisis being experienced by philosophy in relation to the real is not a contingent historical product, but is instead a crisis at the core of philosophy itself. In other words, from the New Realist perspective the antirealist commitments of contemporary philosophy are the product of a series of errors, whereas for Jacobi the antirealist insufficiency of philosophy is the product of philosophy's own essence. If it is the case that coherentism cannot fulfil philosophy's desires, then we must confront anti-realism as the essence of philosophy and not a contingent historical outcome in order to orient ourselves beyond what Jacobi identified as nihilism.

The first part of this essay outlines Ferraris' criticism of postmodern constructivist philosophy by presenting the philosophical genealogy he claims to be the wellspring of the "transcendental fallacy," understood as the conflation of epistemology and ontology. The second part turns to Jacobi's criticism of the essence of philosophy as dependent upon collapsing the infinite distance between the finite and the infinite. And, again, the outcome of this collapse is madness itself. The third part outlines the role of passivity, authority and inscrutability in the realisms of Jacobi and Ferraris. I show that though there are surface differences between Jacobi's God and Ferraris' unamendable real, they serve an identical function. This functional homogeneity belies the deeper connection between New Realism and what John Milbank has called Jacobi's "fideistic realism" (Milbank 1999: 32). The fourth part then outlines a Kantian opening to a post-Kantian-inspired path away from the anti-Enlightenment acquiescence to a rationally inscrutable authority that grounds truth 
and meaning. The overall goal of this comparison is to argue for a return to post-Kantian, speculative philosophies of the Absolute in response to reemerging problems in naturalist and realist philosophy. It is this return to the post-Kantians that can bypass the naïveté and misplaced novelty of New Realism.

\section{1}

To concisely present New Realism as Ferraris articulates it, let us follow the philosophical history Ferraris constructs in an attempt to articulate the novelty of New Realism. In the introductory remarks of the Introduction to New Realism (2015a), Ferraris gives an autobiographical summary of the motivations behind and core tenets of New Realism. Ferraris depicts himself as a valiant rebel against his teachers. He characterizes his response to the work of Hans-Georg Gadamer, Gianni Vattimo, and Jacques Derrida as grounded in an intuition: "I began to think that antirealist positions are actually inappropriate, from a political standpoint" he writes (Ibid: 5). So, Ferraris begins with a political intuition: Something about philosophical antirealism was playing a detrimental role in the social and political sphere. The source of antirealism in the above thinkers and contemporary philosophy more generally is, according to Ferraris, a conflation of epistemology and ontology, what he calls the "transcendental fallacy." Ferraris first introduces this fallacy in Goodbye Kant! What Still Stands of the Critique of Pure Reason (2013 [2004]: 43-48). He continues this narrative in his more recent publications: "I believe philosophical thought has been marked by a confusion between ontology (what there is) and epistemology (what we know, or think we know, about what there is)" (2015a: 6). To illuminate the relation between the conflation of epistemology and ontology as well as the political consequences this conflation entails, Ferraris provides an almost comical narrative of constructivism and postmodernism. ${ }^{3}$ The problems of postmodernism, he claims, lay nascent in the linguistic turn (in both continental and analytic philosophy), but they are not reducible to the turn to language itself.

${ }^{3}$ I say comical because it is almost impossible to find an actual articulation of the kind of radical constructivism that Ferraris believes to be omnipresent in contemporary philosophical discourse. I cannot honestly think of a philosopher who would need to be reminded, for example, that mountains are not social constructs: "This negativity, however, triggered an uncontrollable process, and in particular the idea that everything, including lakes and mountains, is socially constructed" (Ferraris 2015a: 17). 
Ferraris writes "the linguistic turn was the result of a conceptual turn, characterized by a prevalence of concepts in the construction of experience" (Ibid: 12). "In the end" Ferraris continues, "this was the true great postmodern theory: reality is constructed and therefore, ultimately, reality does not exist independently from the representations of an unspecified mankind" (Ibid: 18). The initially epistemic claim that all knowledge is the product of construction is illegitimately transformed into the ontological claim that all reality is constructed in accordance with the powers and procedures through which knowledge is constructed. This extreme constructivist position follows from three other fallacies isolated by Ferraris: 1) the fallacy of being-knowledge, 2) the fallacy of ascertainment-acceptance, and 3) the fallacy of knowledge-power. ${ }^{4}$

Of these three fallacies, the first and third are the most important for unpacking Ferrari's criticism of postmodern philosophy. The fallacy of being-knowledge is the result of a "confusion between ontology and epistemology" (Ferraris 2015a: 24). This is not yet a full conflation of being and knowing, but it arises in light of Cartesian-style skepticism about the correspondence between mind and world. This confusion generates an asymmetrical relation between epistemological claims and ontological conclusions. In other words, in an attempt to undermine skeptical worries of the possibility of knowledge, concepts come to determine not just the intelligibility of objects, but the very being of objects. "I think, I am" implies by extension "I think, therefore the world is," insofar as it is through the self-certainty of myself as a thinking being that I can inferentially be certain of the existence of the world. By extension, in coming to know the world, we actually construct the very world we seek to know by placing our self-knowledge at the center of knowing more generally. This then opens the door for the third of Ferraris' fallacies; the fallacy of knowledge-power is the commitment "according to which behind any form of knowledge there hides a power experienced as negative" (Ibid: 25). The idea here is that the determinate conditions of discursive space are equally determinative of the real objects of discourse. If a) the practices of knowledge production determine being, and $b$ ) behind all knowing there is hidden power, then c) being is determined by power.

To concretize the prehistory of the postmodern endgame of philosophy in which we find ourselves, Ferraris outlines the philosophical personas of "Deskant" and "Foukant" (2015a: 24-29). Each plays a part in constructing a narrative that leads up to the conclusion

\footnotetext{
${ }^{4}$ See Ferraris (2014 [2012]: 23-28, 45-47, 65-68; 2015a: 24-25).
} 
that reality itself is essentially a construction. The short story here is that a) the skeptical worries of René Descartes, b) Immanuel Kant's insight into the constitutive role the subject plays in the shaping of intelligible experience, and c) Michel Foucault's uncovering of the relationship between knowledge and power results in the reduction of reality to the ebbs and flows of power in the institutions and practices of knowledge production. The result is a kind of "might makes right" reality. If power constructs the schemes that in turn construct reality, then the real is nothing but the whims of power.

It is in this way that the world itself becomes indistinguishable from power. The conflation of being, knowledge, and power leaves no room for a reality that would exist independently of the discursive and institutional practices that make knowing possible (what Ferraris reductively calls "conceptual schemes" throughout his writings ${ }^{5}$ ). Unfortunately, countless examples from contemporary social and political life seem to demonstrate the truth of this argument. It is not at all challenging to turn on the TV and see some talking head scream "Fake News" out of one side of their mouth while spewing vile propaganda out of the other. It is no longer impossible for a measly 140 characters to create an alternate reality that conditions the motivations of millions. The possibility of alternative facts generating an alternate reality is a symptom of the philosophical crisis of postmodern constructivism. The most consequential of decisions are made in reference to a hallucinatory ground, a false history, a vacuous unreality. Deskant and Foukant have had their revenge, and we are all caught in the web of this crisis. Or so the story goes.

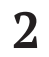

Though he frequently invokes Friedrich Nietzsche's argument that the authority of objective truth has fallen leaving only interpretation in its wake, Ferraris claims that the problem of postmodern antirealism is in fact the "terminal stage [...] of a crisis in German Idealism" (Ferraris 2015a: 20). I take this claim to be correct. There is indeed a kind of crisis of German Idealism that is playing itself out in contemporary philosophy. However, I think there is a fundamental misunderstanding of Ferraris' own position in relation to this crisis. Despite not using these terms, Jacobi (a novelist, literary critic, and self-proclaimed non-philosopher) too constructs a criticism of philosophy that links together epistemology, ontology, and

${ }^{5}$ See, for example, Ferraris (2013 [2004]: 49-57) as well as throughout Ferraris (2015a) and (2015b). 
politics. Further, like Ferraris, Jacobi's worry about philosophy was not reducible to a skeptical one. Jacobi is driven to horror not by the error of idealism, but by its very essence. Ferraris claims a propos postmodernism that " $[u]$ nlike ancient skeptics, postmodern constructionists do not doubt the existence of the world; they claim it is constructed by conceptual schemes and that it is therefore amorphous and indeterminate in itself" (Ferraris 2014 [2012]: 31). The problem is not skepticism, or a doubt in the world, but instead an unshaken faith in the reality of a world constructed by the finite mind. This, in large part, mirrors an attack Jacobi targets at those in his own philosophical milieu. In short, for Jacobi, the conflation of epistemology and ontology occurs by way of "concept collapse" in which the philosopher takes their voice to be equal to God's. That is, the philosopher unknowingly believes that their words create the reality to which they correspond. By extension, transcendental idealism according to Jacobi is nothing short of madness. Finally, to bypass the fatal flaw at the heart of philosophy, Jacobi too proposes a return to a realism predicated upon the passive relation to transcendent authority.

Jacobi's most lasting legacy, from which he has been largely erased, is popularizing the term "nihilism" in his 1799 open letter responding to the philosophical system of Johann Gottlieb Fichte (Jacobi 1994). Therein, Jacobi explains that he "first found entry into the Doctrine of Science through the representation of an inverted Spinozism" (Ibid: 502). There is much to unpack here, but minimally for my present purposes, it highlights the role Spinoza plays in Jacobi's criticism of philosophy, and this in turn brings us back some fourteen years to another of Jacobi's public confrontations. Jacobi's writings on Gotthold Ephraim Lessing and Spinoza ignited what is known as the pantheism controversy. The much-abridged historical version of the controversy centers around the 1785 publication of Jacobi's "Concerning the Doctrine of Spinoza in Letters to Herr Moses Mendelssohn” (1994 [1785]: 173-251). In addition to presenting his interpretation of Spinozism, Jacobi took what proved to be a step too far by claiming that Lessing had confessed to him in private that he himself was a Spinozist. Given that Lessing died four years prior to the publication of Jacobi's incendiary text, there was no way to directly verify Jacobi's disclosure. Subsequently, Moses Mendelssohn attempted to preserve the honor of his deceased friend by defending Lessing against Jacobi's charges. ${ }^{6}$

${ }^{6}$ Friedrich C. Beiser (1993) nicely details and dramatizes the complex set of events that occurred in a brief span of time following the publication of Jacobi's 1785 work so I refer the reader there if it is a more historical retelling of the events they seek. 
If it is in fact the case (and I believe it is) that there is something about the transcendental fallacy as analyzed by Ferraris that expresses a "terminal stage [...] of a crisis in German Idealism" (2015a: $20)$ then the first to diagnosis this crisis was Jacobi. Ferraris may isolate some of the symptoms of this crisis, but he is far from providing a sophisticated articulation of its root causes. For Jacobi, the crisis of German Idealism was nothing less than madness, and from this madness he recoiled in fear. He delivers this diagnosis succinctly in his dialogue "David Hume on Faith or Realism and Idealism" (1994 [1787]: 253-338 ). In the dialogue between the characters "he" and "I," "he" makes the following claim with which "I" agrees:

You forget Wahnsinn, "madness" or being "out of one's senses," a word, whose meaning strikes upon me quite forcefully at the moment. We say that a man is out of his senses when he takes his images to be sensations or actual things. And thus we deny that he is rational, because his representations, which he takes to be things, lack the thing, or the sensible truth-because he regards something as actual which is not. (Jacobi 1994: 303)

"He" and "I" agree that the idealist flirts with madness when thinking lacks actual content insofar as representation itself is granted reality. Against those who would dismiss Jacobi as an unsophisticated irrationalist, we can see that he in fact offers a deep insight into the possibility of philosophy. It is not contingent that philosophy ends in the madness of idealism; it is instead the necessary outcome of the apex of philosophy. To unpack why this is the case, we must turn to Jacobi's primary target: Spinoza. Jacobi and the large majority of his philosophical contemporaries considered Spinozism to be the apex of dogmatic philosophy. Thus, the history of the critique of Spinoza is nothing short of the history of the very essence of philosophy.

Jacobi's incendiary and polemical work on Spinoza's "doctrine" is considered by many commentators not to be a genuine philosophical engagement with the work of Spinoza but instead a thinly veiled attack on his contemporaries and what he perceived as the decline of German piety, and this is not completely false. In contemporary terms, Jacobi was nothing short of a philosophical culture warrior fighting the remnant of Spinoza in order to reclaim the wayward soul of Germany. ${ }^{7}$ In the end, for Jacobi, Spinozism was more than

\footnotetext{
${ }^{7}$ Not unlike contemporary conservative pundits who lament the ills of hip-hop, death metal, video games, and digital technologies. All novelty is feared to be a poison deteriorating the very fabric of "traditional" sociality.
} 
a philosophy; it was a way of life and even a religion. This is evident in the very opening pages of the initial 1785 publication of "Concerning the Doctrine of Spinoza," when Jacobi claims to have asked Elise Reimarus (a "close friend of Lessing's") "how much, or how little, Mendelssohn knew of Lessing's religious inclinations" (Jacobi 1994 [1785]: 181). In this exchange Jacobi is not concerned with philosophical positions but instead the entire religious worldview of Lessing. He then writes the infamous lines that began the controversy: "I said that Lessing had been a Spinozist" (Ibid). Again, according to Jacobi, Lessing did not merely have particular philosophical leanings toward Spinozism; Spinozism was his religion, and this was tantamount to having no religion at all. David Janssens captures this nicely when he explains: "[w]ith unrivaled clarity, Jacobi argues, Spinoza's thought shows that the common root of the Enlightenment's philosophy and politics is a rebellious and revolutionary effort to liberate man from the authority of transcendence" (Janssens 2003: 611). So, just as Ferraris takes postmodernist constructivism as a philosophical position with cultural, social, and political repercussions, Jacobi believed Spinozism to be much more than just a philosophy. Spinozism was at its very core a rejection of a particular formulation of authority, reason, and world. This is the formulation in which transcendence is granted absolute authority over the terrestrial affairs of knowing. Again, the problem is not with just a philosophical position or a collection of propositions about the world; Jacobi's fear arises in response to the rejection of the very notion of transcendent authority in relation to which knowledge is completely passive.

So, in broad strokes, the philosophical core of Spinozism entails a commitment to the authority of reason and a rejection of transcendence. As Michael Della Rocca (2008) has argued, the Principle of Sufficient Reason (PSR) is fundamental to generating each of Spinoza's most well-known doctrines, such as existence monism and the parallelism of the attributes. It is therefore quite appropriate that the primary idea Jacobi interrogates in order to make this case as to the essential insufficiency of philosophy is the PSR. Jacobi delves most extensively into the consequences of Spinoza's commitment to the PSR in a supplement to "Concerning the Doctrine of Spinoza in Letters to Moses Mendelssohn" added in the second edition of 1789 (1994 [1789]:339-78). There he states the principle in two ways, first "[e]verything dependent depends on something," and second, "[e]verything that is done must be done through something” (Jacobi 1994: 372, italics removed). The two taken together in their most general formulation form "[e]verything conditional 
must have a condition" (Ibid: 372 ). To make a long story short, this necessary chain of conditions and causes calls into question the very intelligibility of a beginning, and the possibility of externality by extension. If every effect must be conditioned by a prior cause that is in turn the effect of an even prior cause, then this leads to a totalizing infinite regress. Jacobi in fact praises Spinoza for embracing the consequences of this fact instead of violating his commitment to the PSR. "This immediate, eternal mode" Jacobi writes, "that he believed to be expressed by the relation of motion and rest in natura naturata, was for him the universal, eternal, unalterable form of individual things and of their unceasing change" (Ibid: 370). Jacobi then continues,

If this movement did not have a beginning, individual things could not have begun either. Not only were these things eternal in origin, therefore; they also, according to reason, existed simultaneously, regardless of their succession: for in the concept of reason itself, there is no prior or posterior, but everything is necessary and simultaneous, and the one and only consequence permitted in thought is that of dependence. (Jacobi 1994: 370)

Passages like this make clear the depth of Jacobi's understanding of Spinoza. For example, he clearly connects the necessity of substance as totum analyticum ${ }_{-}^{8}$ and the PSR when he writes of the lack of prior and posterior for reason. Moreover, he uses the same language of conditioned and condition found in Kant's analysis of the PSR (to which I turn in section 4). These convergences demonstrate that Jacobi and Kant focus on the same soul of Spinoza's philosophy; they think through what Pierre Bayle had called Spinoza's most monstrous thought (his existence monism) but refuse to stop there. ${ }^{9}$ Both Kant and Jacobi seek to go beyond Spinoza's conclusions in order to better understand the reasons he gives for these monstrosities. What is fascinating about this convergence is that it shows both "sides" of the controversies around idealism and

${ }^{8}$ The notion of totality as totum analyticum is contrasted to that of a totum syntheticum. In the latter, totality is the end result of an additive process or is constituted by the amalgamation of individual parts. The former, on the other hand, is a totality given at once prior to and indifferent to the existence of component parts. As Omri Boehm has argued, it is this notion of totality given at once with which Spinoza operates, whereas it is the notion of totum syntheticum against which the Kantian antinomies take aim. See Boehm (2014).

${ }^{9}$ See Bayle (1991 [1740]: 296-97). Of Spinoza's conflation of God and world, Bayle writes that it is "the most monstrous hypothesis that could be imagined, the most absurd, and the most diametrically opposed to the most evident notions of our mind." 
nihilism are born from a shared criticism of Spinozism. In other words, though Jacobi and the post-Kantian idealists largely talk past each other, both remain in fundamental agreement over Spinozism. Both Kant and Jacobi realize that to combat Spinoza in the name of freedom and nature, the limits of reason and the scope of philosophy must be brought into sharper focus. Kant argues that it is possible for reason to take itself as its object and immanently demonstrate its own limits. Alternatively, Jacobi argues that reason must assume a fundamentally passive relation to the real that it seeks to know. For Jacobi, the problem is that if the scope of reason is infinite, then there can be nothing outside of reason. Taken in combination with the philosopher's resolute commitment to the PSR, this would leave the philosopher trapped in an immanence with no externality. Only nothing would lie outside of philosophy, and if nothing can come from nothing, then philosophy is unable to account for its own explanatory capacities.

With this general introduction to Jacobi's attack against Spinozism and the Enlightenment's faith in the scope of reason more generally, let us now turn to the specific epistemological problem presented by Jacobi as it returns us to the above discussion of Ferraris. "Our philosophical understanding does not reach beyond its own creation" Jacobi writes (1994: 370). By this he means that philosophy can only come to know that which it creates for itself. John Millbank (perhaps the most influential contemporary defender of Jacobi's thought) comes close to grasping this general idea:

[I]f pure reason can accept as real only the identically repeated according to logically necessitated laws, then a fated chain without meaning must float above an abyss identified by the fundamental law of identity: $a=a$. This abyss is the underlying real, and yet it is nothing; the only "something" is the phenomenal fated flux, yet as only phenomenal this is also nothing. (Milbank 1999: 26)

Milbank's claim here is that when reason relates only to itself, it has no ground. It consequently "floats above" this lacking ground, this void, and therefore relates to nothing other than itself. What we must attend to, à la Jacobi, is that from the philosophical point of view, that is from the view firmly committed to the PSR, philosophy can only come to understand the content that it provides to itself. The PSR eviscerates itself in the deepest of possible ways: In striving to know all things, it turns all things into shadows, it balances itself untenably upon an abyss. Again, if nothing can come from nothing, and there is nothing outside of philosophy, then philosophy has 
only itself and its internal productions. Consequently, thought lacks "the thing," and the thinker is indistinguishable from the madman.

This analysis of the immanent flaws of philosophy is far-reaching, but it can be formulated in a kind of punctuation mark, not quite a fallacy as Ferraris describes them but as a persistent threat. We can find this more specific formulation of philosophy's epistemic shortcomings in Jacobi's "David Hume" (1994 [1787]). Therein Jacobi discusses what I call "concept collapse." Though he will come to a radically different solution to this dilemma, John McDowell voices a similar concern. In reference to the mind's capacity for the conceptual determination of non-conceptual givens, McDowell writes "[w]e need to conceive this expansive spontaneity as subject to control from outside our thinking, on pain of representing the operations of spontaneity as a frictionless spinning in a void" (1996: 11). McDowell's worry here is that there must be some kind of constraint that exists external to spontaneous conception if concepts are to be at all grounded in relation to objects. Jacobi's fear can be formulated similarly; if philosophy relates only to itself, then there can be no extra-philosophical constraint to which philosophical claims are beholden. The philosopher can unpack the inferential relations internal to the objects it creates for itself, but it is fundamentally unable to account for the actuality of these objects. It plays with shadows and takes this game to be real.

For Jacobi the inevitability of concept collapse stems from the finitude of the human subject and the incapacities of finite speech. In a discussion of the relationship between language and representation, Jacobi emphasizes the consequences of the finite nature of the speaking subject: "But these words begotten of finite seed are not like the words of $\mathrm{He}$ Who Is, and their life is not like the life of the spirit that calls being forth from nothingness" he explains (1994 [1787]: 306). As the authority of John 1:1 would have made clear to Jacobi, the word of God creates simply by virtue of being spoken. The enunciation of the infinite's articulation is sufficient for the finite's instantiation. Alternatively, the finite word does not create its referent from itself and through its own act of enunciation. Finite speech is dependent upon the actual existence of the things it names (minimally, the actual existence of some external constrain to which conceptual productions are responsive). Jacobi then presents the consequence of collapsing the relationship between finite word and thing: "The moment we lose track of this infinite distinction, we remove ourselves from the source of all truth: we forsake God, Nature, and Ourselves" (Ibid: 306, own emphasis added). The collapse of any externality, be it on the side of either substance or 
intellect, eliminates the possibility of truth. This erasure of the very possibility of extra-conceptual content turns the philosopher into a sleepwalker, a mere navigator of bottomless dreams: "with the philosophical dream, we only slide deeper and deeper into it, until we finally rise to the perfection of a most wondrous somnambulism", Jacobi writes (Ibid: 306). So, not only is philosophy incapable of producing the objects to which its concepts are supposed to correspond, it is likewise unable to wrest itself from the its own dream state in which it deliriously believes its operations to be sufficient. Jacobi too fears a philosophy that is spinning frictionlessly in a void and thus from Jacobi's perspective, the philosopher's dream quickly becomes a nightmare.

\section{3}

We have now laid out the criticisms of their contemporaries found in both Jacobi and Ferraris. Both fear that the philosophy of their contemporaries tended toward a kind of coherentist idealism. Jacobi calls this nihilism and Ferraris calls this postmodern constructivism. In response to this fear, both explicitly and resolutely turn to realism as a remedy for the madness of idealism. "The antithesis to nihilism, in Jacobi's sense, is realism," Friedrich C. Beiser explains, "where 'realism' is defined in a broad sense as the belief in the independent existence of all kinds of entities, whether these be material things, other minds, or God" (1993: 82). For his part, Ferraris claims that

if the realist is the one who claims that there are parts of the world that are not dependent on the subjects, the new realist asserts something more challenging. Not only are there large parts of the world independent of the cogito, but those parts are inherently structured, and thus orient the behavior and thought of humans as well as animals. (Ferraris 2015a: 37)

Now Jacobi and Ferraris articulate distinguishable notions of realism but there is at bottom a characteristic they both share, and this characteristic determines their respective realisms as fundamentally reactionary and counter to the spirit of Enlightenment. In general, I follow Foucault's minimalist definition of Enlightenment as "a modification of the pre-existing relation linking will, authority, and the use of reason" (1984: 34-35). Enlightenment is not reducible to a particular historical period, a set of thinkers or even a unified set of commitments. The Enlightenment project is instead an ongoing act of renegotiating existing configurations of will, reason, and 
authority. What Jacobi (explicitly) and Ferraris (implicitly) reject is that the relation between will, reason, and authority is modifiable. This is evidenced most clearly by the role that passivity plays in relation to the real ground of truth for both thinkers. For both, if reason and will reorganize themselves in order to take an active stance toward the constitution of authority, reality in turn slips into nothingness. Now, the point I am seeking to establish is not that either reason or will are in themselves an absolute authority, but instead that reason and will both must play an active and passive role in the practices of conceptual constitution and determination in response to certain constraints. To limit will and reason to vehicles of passive reception of constraint robs each of its reformatting potential. When the constrain of the real is premised upon a passive relation to authority, authority is essentially rendered transcendent. This insistence that the authority of the real is made possible by its absolute transcendence is the root of anti-idealist dementophobia.

For Jacobi, the intertwined themes of faith, life, and passivity are united through the constitutive transcendence of God to the world that Jacobi takes as self-evident. As the epistemic case of concept collapse shows, there must be an infinite distance between the infinite (that which gives meaning and order) and the finite (that which comes to know the divine creation). The authority of transcendence must be absolute and absolutely external. It is on the basis of this assumption that faith becomes necessary. The gap between the divine and creation must be bridged, but it cannot be bridged in such a way that it is collapsed. If we follow Jay M. Bernstein's characterization of faith as "an absolute relation to the absolute" we can easily see how this is the best possible candidate for this role (2017: 265). It is only this non-communicative, rationally inscrutable, absolute relation that does not determine through subsumption and thereby destroy its own ground.

Turning to Jacobi's accusation of nihilism makes this configuration of authority, transcendence, and faith more clear. What could be called Jacobi's epistemology is found in his open letter to Fichte published as "Jacobi to Fichte" (1994 [1799]: 497-536). Therein he laments Fichte's "philosophy of one piece” (Ibid: 510) and proclaims "I understand by 'the true' something which is prior to and outside knowledge; that which first gives a value to knowledge and to the faculty of knowledge, to reason" (Ibid: 513). The true, that is the very possibility of truth, is necessarily dependent upon its priority to and externality from all knowledge. If it could be known then it would no longer be true. Jacobi's crescendo of sorts is then articulated in the following dramatic lines: 
Man has this choice, however, and this choice alone: Nothingness or a God. If he chooses nothingness, he makes himself into a God, that is, he makes a phantom into God, for it is impossible, if there is no God, that man and all that surrounds him should be anything but a phantom. I repeat: God is, and is outside me, a living, self-subsisting being, or I am God. There is no third. (Jacobi 1994: 524)

It may seem at first that this dramatic decision between God and nothing could not be further from a philosophy that professes to be a New Realism. However, it is precisely this logic that lies at the core of Ferraris' New Realism. Again, the primary focus must be on the notions of externality, life, and self-subsistence. Working backward, just as Ferraris claims of the real, for Jacobi God exists independently of the mind, God is without the need of mindedness to be ordered, and God is absolutely (ontologically) external to the subject. All being, knowing, and goodness are determined by the unnegotiable authority of this absolute externality. The authority of this transcendent externality is premised upon the infinite distance between the infinite and the finite. Let us return to Ferraris to further spell this out.

At the core of Ferraris' realism also lies an extra-conceptual kernel that is necessarily and always outside of the purview of rational scrutiny. Though he does not call it "God," this difference is not one that truly makes a difference. The central tool for resisting postmodern constructivism in Ferraris' realism is what he calls the "unamendability" of reality. ${ }^{10}$ At the most basic level, the idea here is that reality is indifferent to human conceptual schemes. Ferraris appeals to common experiences to elucidate this point. What we expect to be the case does not always come to be the case, and we can be wrong about reality. And, further, reality can still appear to us as it should not, regardless of our knowledge of it (as the example of a pencil in water might illustrate). Significantly, this is not just a claim about the penetrability of the real by the mind. The unamendability of the real is causally determinative (in a non-conceptual way) of the mind. "The unamendability of the real determines the non-conceptual content of experience," Ferraris writes (2015a: 39).

Ferraris' claim is not reducible to a mysticism about the real (that which is real is inaccessible to thinking insofar as it is defined as being indifferent to it). Thought must be responsive to the reality that resists it, and it must be capable of saying true things about this reality. This in turn leads to Ferraris' conceptualization of a "dual

\footnotetext{
${ }^{10}$ See Ferraris (2015a: 37-40).
} 
aspect reality." One the one hand, there is "epistemological reality" that is "linked to what (we think) we know about what there is," and on the other hand there is an "ontological reality," "which refers to that there is whether we know it or not, and what manifests itself both as resistance (unamenability) and as positivity" (Ibid: 41). First, because of the New Realist rejection of the transcendental fallacy, epistemic and ontological reality must be separated absolutely; to fail to demarcate and maintain this separation results in a return to the problems of constructivism. What the negative-positive distinction is intended to accomplish here is to allow for knowledge of a world independent of us as knowing beings (at times what we think about what is does in actuality map onto what is the case) while at the same time allowing the real that we can come to know remains indifferent to this knowledge. Ferraris again:

On the one hand, we should maintain that there is an unamenable kernel in being and experience that gives itself in complete independence from conceptual schemes and knowledge. On the other hand, we must leave open the possibility of constructing, starting from this unamenable layer, knowledge as a conceptual, linguistic, deliberative, and especially emancipatory activity. (Ferraris 2015a: 43)

There is an absolute externality of ontological reality to epistemic reality. As we saw with the case of the transcendental fallacy, the conflation of one with the other vitiates the existence of either. This brings us back to the function of faith in Jacobi. Faith was necessary for the finite mind to bridge the infinite gap between the infinite and the finite without collapsing it on the side of finitude. This collapse results in the closed, self-referential nexus of philosophical hallucination. For Ferraris, it is the notion of experience that plays this bridging role. Experience always has within it some kind of non-conceptual kernel. Through the mediation of experience (somehow both proto-conceptual and non-conceptual), epistemic reality can be constructed "upon" ontological reality. For Jacobi, it was through the active assumption of passivity in relation to divine life (what he calls the salto mortale, a death-defying leap back into the immediacy of the real) that the finite mind was able to know divine creation as it is ordered by the divine mind. Jacobi argues that divine life is the shared logic of both reality and knowledge. Ferraris' above suggestion is that experience somehow plays a similar role to faith. He suggests that New Realism begins from empirical observations of the incongruence of epistemic and ontological reality in cases such as error and illusion. 
Crucial to this discussion are relations of activity and passivity. "[T]he constructionist claims that reality is docile in respect to out purposes, while the negative realist objects that it can also say 'no' to us” Ferraris explains (2015a: 47). Whereas for the postmodern constructivist, reality is always passive in relation to the always active practices of conception, for the negative realist, reality is active in its resistance to this practice of conceptual schematization. Ferraris believes himself to be articulating a "positive realism" that takes one step beyond this observation of negative realism. This depends upon a "dialectic" between the negative resistance of reality and the positive affordances given by reality. However, Ferraris' dual aspect realism of ontological and epistemic realities seems to foreclose the intelligibility of this dialectical mechanism, once again rendering New Realism dependent upon a rationally inscrutable core. This theme of inscrutability returns us to the necessity of externality. For example, Ferraris writes of values that "something has value precisely because it comes from outside, otherwise it would be nothing but imagination" (Ibid: 48). Contrasting this sentiment to one voiced by Jacobi to Fichte reveals that the overlap between Jacobi and Ferraris is more than formal:

Everything that I have called good, beautiful and holy, would become for me a non-entity that shatters my spirt and tears the heart out of my breast, the moment I accept it exists without connection in me to a higher and true Being, without being in me only symbol and image of this Being [...]. (Jacobi 1994: 515)

Without the actual existence of the extra-ideational Being beyond knowledge, all the values of a life worth living are robbed from Jacobi. As a consequence, his very being is torn to pieces, his spirit shattered and his beating heart removed. Combining Jacobi and Ferraris on this point, we can say that the transcendence of ontological reality is a necessary condition for the actuality of epistemic and moral claims. Epistemic reality (in which knowledge and emancipation are constructed passively) relates to ontological reality through the extra-conceptual operations of the experience of being as resistant to the schemes of knowing. In short, for both Jacobi and Ferraris, without the authority of transcendence, there is nothing true, nothing good, and ultimately nothing at all.

To repeat, at bottom, for both Jacobi and Ferraris the function of conceptuality must take the "real" as an external, transcendent and therefore inscrutable authority to which one must assume a position of absolute passivity. Thus, if the pantheism controversy was a work- 
ing-through of the relation between the scope of rationality and the traditional limits of authority, Ferraris finds himself squarely on the reactionary, counter-Enlightenment side of Jacobi, ultimately safeguarding the transcendence of authority from developments in the natural and social sciences. If this is indeed the case, Ferraris' New Realism is fundamentally conservative despite his many claims to the contrary. Take for example his claim that

[o]n the one hand, we should stick to the fact that there is an unamendable core of being and experience that gives itself in complete independence from conceptual schemes and knowledge. On the other hand, we must leave open the possibility of constructing, upon this layer, knowledge as a conceptual, linguistic, deliberative, and above all emancipatory activity. (Ferraris 2014 [2012]: 58)

The "unamendable core of being" stands absolutely opposed to conceptual schematization, there is an infinite distance between the two. For Jacobi, it is faith as a rationally inscrutable, passive relation to the infinite through which the real gives itself over to knowledge. Ferraris too relies on this model of non-conceptual, rationally inscrutable, passivity. In this sense, New Realism is not just reliant on a non-conceptual basis for the conceptual, it is actually anti-conceptual at its core. On the level of conceptuality (understood more broadly as discursive and linguistic systems and institutions of knowledge production ${ }^{11}$ ), we should actively strive toward emancipation. However, this emancipatory logic remains beholden to an ontological ground that it cannot know, that it cannot question and that it cannot change. ${ }^{12}$ Emancipation is nothing if it is not real; that is, if one denies the ability of reason and will

${ }^{11}$ To be fair to Ferraris, he does outline a detailed theory of what he calls "documentality" that seeks to account for the reality of social, conceptual space. He defines documentality as "the environment in which social objects are generated" (Ferraris 2015a: 63). The problem is that even within this social space, the reality of its objects remains characterized by unamendability. The reality of the social object remains that "part" of it which resists conceptualization. So even within social space, reality's core remains an anti-conceptual authority to which the subject is passively beholden.

${ }^{12}$ I think at this point one can see an overlap between the New Realism of Ferraris and that of Markus Gabriel. As I have briefly argued elsewhere (Norris 2015), the notion of "field" so prevalent in Gabriel's current ontology of fields of sense remains both central (to exist is to appear in a field of sense) yet functionally enigmatic. I continue to fail to see how a field is able to "grant" existence to the things which appear within it. Further, for a field to be "real" it too must appear in some field of sense, triggering a regress into trans-finitude. Consequently, there is enough affinity between the unamenable real and the field which bestows sense by mechanisms unknown to worry me. 
to actively reformat their relation to authority, one erases the very possibility of emancipation. In other words, for the reactionary, the pre-existing configuration of reason, will, and authority must be maintained at all cost. If reason and will dare to renegotiate their relation to authority, they risk their very existence. We are told that any renegotiation of this relation will result in the evaporation of all meaning and truth. Thus, New Realism is in fact forced into Jacobi's dilemma: the decision between nothing (either nihilism or postmodern constructivism) and transcendent authority (either God or the real). There is no third and one must choose.

\section{4}

I now want to turn to Kant and what I see as a source from which one can draw in order to circumvent Ferraris' caricature of postmodern constructivism while also re-engaging with naturalism and realism in a postcritical manner. Ferraris draws many of his conclusions regarding Kant and the Critique of Pure Reason from just a few sections of the Transcendental Doctrine of Elements (2003 [1787]: A17/B31-A704/B732), wherein one can find Kant's arguments regarding the a priori nature of space and time, the categories in accordance with which experience is intelligible, and the deduction of the applicability of these categories as well as the "I think" that must accompany all my representations. Ferraris is not alone in thinking that one can just say goodbye to these Kantian conclusions in the wake of the recent return to realism. Many realist attacks on Kant focus on the claims of the Transcendental Aesthetic (Ibid: A19/ B31-B73) and the first book of the Transcendental Analytic regarding the Analytic of Concepts (Ibid: A64/B89-B199). This generates a lopsided approach to Kant's already controversial first Critique. Consequently, we are told to say goodbye to Kant without serious consideration of the findings in the Transcendental Dialectic of the Critique of Pure Reason (Ibid: A293/B349-A704/B732), which Kant himself suggests is the ultimate indirect proof of the necessity for transcendental idealism.

Let us take a brief look at the Transcendental Dialectic in order to outline some essential resources Kant provides for avoiding the conflation of ontology and epistemology feared by both Jacobi and Ferraris. In doing so, we will see that these resources open a space for moving past the passive acquiescence to transcendence (understood as any kind of rationally inscrutable authority whose inscrutability is made possible by absolute externality). In the Transcendental Dialectic, the self-examination of reason turns to its own core; it is 
there that Kant spells out what we might call reason's desire. For Kant, what the Transcendental Dialectic shows is that the capacity of reason is unequal to its desire, and this is its tragic fate so artfully described in the preface to the first edition of the Critique of Pure Reason. ${ }^{13}$ Briefly turning to this tragic fate and the desire that leads to it outlines what we can take as Kant's own critique of Ferraris' "transcendental fallacy."

The Transcendental Dialectic operates by way of an immanent critique of the scope reason assumes for itself when making psychological, cosmological, and theological claims. Kant identifies three of what he calls "transcendental illusions": the soul, the world, and God. Each serves as a cornerstone for rational psychology, cosmology, and theology respectively. Further, instead of shoring up these cornerstones of all prior metaphysics, Kant argues that these illusions are necessary yet inexistent points of orientation for systematic understanding. ${ }^{14}$ Kant unpacks how these necessary points of orientation can become metaphysical traps through a kind of short-circuiting of reason's desire. This glitch within reason is more than an accidental error in the functioning of reason.

Kant introduces the "logical employment" of reason in the following:

Reason, in its logical employment, seeks to discover the universal condition of its judgment (the conclusion), and the syllogism is itself nothing but a judgment made by means of the subsumption of its condition under a universal rule (the major premiss). Now since this rule is itself subject to the same requirement of reason, and the condition of the condition must therefore be sought (by means of a prosyllogism) whenever practicable, obviously the principle peculiar to reason in general, in its logical employment, is: to find for the conditioned knowledge obtained through the understanding the unconditioned by which its unity is brought to completion. (Kant 2003 [1787]: A307/B364)

${ }^{13}$ Kant writes the following of "human reason" in the preface to the first edition of the first Critique: "Human reason has this peculiar fate that in one species of its knowledge it is burdened by questions which, as prescribed by the very nature of reason itself, it is not able to ignore, but which, as transcending all its powers, it is also not able to answer" (2003 [1787]: A vii.) He continues, "[f]or since the principles of which is it making use transcend the limits of experience, they are no longer subject to any empirical test. The battle-field of these endless controversies is called metaphysics"(Ibid: A viii).

${ }^{14}$ Later in the Transcendental Dialectic, Kant argues that the soul, the world and god exist as "ideas" for reason, but not as objects or concepts (2003 [1787]: A642/ B671-A704/B732). 
Reason seeks not just complete syllogisms; when applied to itself, it continues to seek the unconditioned "by which" each conditioned is brought into a complete unity. Kant continues this characterization as follows, "[b]ut this logical maxim" Kant comments in regard to the previous quotation,

can only become a principle of pure reason through our assuming that if the conditioned is given, the whole series of conditions, subordinated to one another - a series which is therefore itself unconditioned - is likewise given, that is, is contained in the object and its connection. (Kant 2003 [1787]: A307-308/B364)

Reason is logically insatiable for Kant; for any given condition another must be sought, and so on, forever. This is the desire of reason. For any given, reason desires to know the entire series of conditions in accordance with which that given is given as it is and not otherwise. Kant's purpose in diagnosing this terminal condition is ultimately constructive in its nature. He is seeking to expose reason's immanent desire in order to demarcate its proper application.

There is a careful distinction that must be drawn between these two principles. In the first quotation, Kant is discussing a task given to the reasoner. In light of any given condition, one must seek to find the unconditioned by which the given conditioned is made possible as thus and so. In the second quotation, Kant is making a related but significantly distinct claim. Therein, he writes of the assumption that for any given condition the "whole series of conditions," the "unconditioned", is likewise given in the same way that the conditioned is given. Thus the first quotation is subjective in its scope (insofar as it describes a task given to the reasoner). In the literature on the doctrine of transcendental illusion this subjective formulation of the principle of reason is referred to as " $\mathrm{P}_{1}$." Alternatively, the second quotation is making an objective claim: if the conditioned is given, then so too is the unconditioned by which the givenness of any particular conditioned is possible. This objective formulation of the principle of reason is nominated " $\mathrm{P}_{2}$." By differentiating between on objective principle of reason $\left(\mathrm{P}_{2}\right)$ from a subjective one $\left(\mathrm{P}_{1}\right)$, Kant lays the ground for understanding what he calls transcendental illusion. Now, importantly, these two principles are emergent from a single impulse. Michell Grier formulates this point as follows:

although $\mathrm{P}_{2}$ appears to be an entirely different principle from $\mathrm{P}_{1}$, Kant's view seems to be that $P_{1}$ and $P_{2}$ express the very same demand of reason, viewed in different ways. Put most simply, $P_{2}$ just is $P_{1}$ 
when it is conceived by reason in abstraction from the conditions of the understanding. (Grier 2001: 124)

This analysis shows that both $\mathrm{P}_{1}$ and $\mathrm{P}_{2}$ are formulations of the PSR, which is, as Jacobi stated and many agreed, the spirit and soul of Spinoza's philosophy that was in turn the only possible consistent philosophy. Thus, in order to better direct reason and quell the "battlefield of metaphysics," Kant turns reason against its own authority in order to renegotiate the appropriate and inappropriate applications of rationality. ${ }^{15}$

Ok, so what is the takeaway from all this? Reason, if it is to become systematic, demands the set of conditions by which any particular condition is rendered possible. No condition is intelligible without being related to the prior conditions that make it possible. Thus Kant is also engaging with the problems that flow from the fanatical commitment to the PSR exemplified by Spinoza's Ethics. From nothing, nothing can come. However, this temporary bulwark against transcendental realism is not a simple formula extractable from the Critique that can be followed by the philosopher afraid of going astray. It is instead a kind of poison pill at the heart of reason's desire. Kant's insight into the machinations of reason shows that reason gives to itself a task it cannot accomplish. Building on this, Kant argues that it is false to assume that the PSR presents the finite mind with an attainable goal. In this sense the PSR in its objective formulation represents a necessary impossibility. If an object is given to the senses this does not mean that the entire series of conditions for that object is also given objectively. For example, space and time are the necessary forms of intuition that make the experience of objects possible. They are particular conditions for any conditioned object (and a priori conditions at that), but one must not in turn posit space and time as objective conditions of objects in themselves. This would be to move from transcendental idealism to transcendental realism, ${ }^{16}$ a position the philosopher must avoid, for "[w]ere we to yield to the illusion of transcendental realism, neither nature nor freedom would remain” (Kant 2003 [1787]: A543/B571).

\footnotetext{
${ }^{15}$ See note 11 above.

${ }^{16}$ In reference to the relationship between Kant's critical project and transcendental realism, Grier explains that "in the Critique, Kant ultimately links the error exhibited by both Locke and Leibniz (that of taking appearances for things-in-themselves) up to the position he refers to as 'transcendental realism.' Although Kant's explicit references to 'transcendental realism' are scant, it does seem clear that he wishes to characterize it as an erroneous position that takes the subjective conditions of space and time, and therefore also spatiotemporal objects (appearances), to be given 'in themselves' independently of our sensibility" (Grier 2001: 98).
} 
So, what is at stake for Kant is in fact twofold: In order to allow for both freedom and nature, we must curtail the immanently necessary yet constitutively unattainable ambitions of reason. What is important to emphasize here is that reason is able to actively know its own limitations through rigorous self-examination. In accordance with these findings, one can more precisely direct and limit the application of rational principles within their own proper scope, and through doing one can freely come to know.

It is this distinction between the proper and improper applications of reason that brings us back to the transcendental fallacy. In short, Kant is warning us not to conflate the subjective order of reasonings with the objective order of causes on pain of falling into illusion. If we take the principle of reason articulated in the subjective form of seeking the unconditioned by means of which any given condition is possible as an objective truth about things as they are independent of experience, we are led into illusion. To formulate the claim in Ferraris' terms, Kant is arguing that the principle of reason is not an ontological fact, and reason goes astray when it is taken to be one. Further, Kant argues that when the principle of reason is restricted to its proper "epistemic" application, it is capable of demarcating its own limits and subsequently navigating the spaces proper to it. The most basic conclusion we can draw from this is that for Kant, ontology does not collapse into epistemology. Put otherwise, the order of objective causes cannot without justification be assumed to be the same as the "subjective" order of epistemic reasons. The same holds true in the reverse: the order of reasons cannot without justification be taken as identical to the order of causes. Consequently, far from sowing the seeds for the transcendental fallacy, Kant's analysis of the limits of what reason can do provides a strict protection against the conflation of the ontological and the epistemological orders.

Regardless of their respective positions on the successes and failures of the Kantian project, both Hegel and Schelling find Kant's separation of understanding from reason to be perhaps his most important innovation. Kant, both argue, did not fully understand what he had done when he divided reason from understanding and applied the former to itself in order to better demarcate the limits of what philosophy can accomplish. Kant assumed that the glitch in reason's function signaled the finitude of reason and the need for faith. Alternatively, Hegel and Schelling take this glitch of reason exposed by reason to be a feature and not a bug. Each rejects Kant's modest conclusions and instead seek a dialectical resolution of reason's findings. 
If we refuse to accept Kant's modesty, the following is necessarily true: the distinction between (epistemic) reasons and (ontological) causes is the beginning to a solution and not a solution in itself. As Adrian Johnston has argued (2019: 259-91), the dichotomy between reasons and causes (often framed as a distinction between [subjective] spirit and [objective] nature), cannot be an absolute distinction if it is to be drawn within a broadly naturalistic worldview. We must establish a dialectical intertwining of the space of reasons and the space of causes if we are to remain naturalists and reject any self-grounding, supernatural (dare I say religious?) account of the coming to be of the subjective space of reasons from the objective realm of causality. That is, if we are to avoid an account of the supernatural genesis of transcendental subjectivity we must take seriously the qualitative emergence of ourselves as reasoning and self-determining beings from an active nature which is itself not presupposed to be rational. ${ }^{17}$ It is this problem of the natural emergence of transcendental subjectivity, among others, that Johnston's transcendental materialism seeks to address. Though this position is complex with much nuance, it finds a motivating insight in an ontological thesis drawn from Hegel's radicalization of Kant. In the Transcendental Dialectic, reason does not expose its own weakness when it demonstrates that the world as a self-enclosed totality of the objects of possible experience does not exist. Instead, by exposing the inconsistency of the notion of a self-enclosed immanent field containing all possibilities, transcendental subjectivity uncovers its very own conditions of possibility. ${ }^{18}$ Johnston concludes the second volume of his Prolegomena to Any Future Materialism with a restating of his position that he describes as "existential-transcendental materialism of weak nature alone," which maintains "a non-unified multitude of natural materialities is the primordial existence in relation to which all essences are internally arising outgrowths that nevertheless come to acquire a transcendent-while-immanent, more than natural autonomy" (Johnston 2019: 290-91). Now, I do not have space to unpack this, but the fundamental takeaway at the moment is the notion of nature as a "non-unified multitude of materialities" that is generative of "more than natural" modes of existence and determination precisely because it is not a unified field of predetermined actualities. Again, Kant's insight that "the world is not an unconditioned whole, and does not exist as such

\footnotetext{
${ }^{17}$ This is perhaps a more complex way of advocating for a rejection of univocal vitalism.

${ }^{18}$ See Žižek (1993) and Johnston (2008).
} 
a whole" paves the way for this ontology insofar as Kant ruptures the assumed confluence of ontological causes and reasons (2003 [1787]: A505/B533). He does this not by reducing one to the other, but instead by dismissing the very notion of a unified totality previously called "the world."

The division between the proper and improper uses of reason is linked to the inexistence of a world understood as a unified whole in the First Antinomy (Ibid: A426/B454-A434/B462). The world (in ideality and reality) is characterized by a constitutive absence of any immanence that is itself without internal strife and rupture. Further, this absence of immanence disrupts the possibility of transcendent externality insofar as absolute externality is premised upon the existence of a self-enclosed totality. It is this notion of self-enclosed totality that Kant begins to undermine, and consequently any strict division between immanence and transcendence begins to crumble. It is this crack in the world Kant exposes that paves the way for a robust, speculative notion of the Absolute. As Hegel writes regarding his then collaborator Schelling, "the Absolute itself is the identity of identity and non-identity; being opposed and being one are both together in it" (Hegel 1977 [1801]: 156). Were there not a fracture in the whole, this whole would not be absolute. That is, it would not be the concrete identity of identity and difference, the unity of self and self-sundering negativity. This in-division of the Absolute avoids the conflation of the causal (ontological) order and the rational (epistemic) order. Additionally it disqualifies the assumption of absolute passivity of subject in relation to object.

\section{5}

From all this we ought to conclude that New Realism is nothing new, insofar as the idea that Kantian-style idealism leads to constructivism and even nihilism is already present in the work of Jacobi. This misplaced sense of novelty recalls Wilfrid Sellars' statement that "[p]hilosophy without the history of philosophy, if not empty or blind, is at least dumb" (1968: 1). The "transcendental fallacy" in which the conflation of epistemology and ontology leads to the conviction that the structures of cognition determine in full the structures of the world restates the fears Jacobi articulated in horror when he confronted Fichte's Ich for which there was no outside (Jacobi 1994 [1799]: 497-536). This nihilism is the inversion of Spinoza's fanatical rationalism, which Jacobi took to be the unavoidable endgame of philosophy itself. The inversion of realist Spinozist 
dogmatism into idealist Fichtean nihilism demarcates equally the subjective and objective shortcomings of the unjustified assumption of equivalence between the subjective order of reasons and the objective order of causes. Consequently, if we read Kant carefully, we see that he was all too cognizant of the transcendental fallacy Ferraris seems to assume that all but he remain ignorant of.

Despite the two centuries separating contemporary philosophy from the writings of Jacobi, the fear of a lost world persists; the fear of the madness of idealism returns. We are warned against one-sided criticism, but in turn we are forced back into one-sided dogmatism. As we have seen, this particular philosophical problematic has always carried with it extra-philosophical concerns about the decimation of the very fabric of sociality. When reason and will take aim at the authority of transcendence, this reactionary backlash occurs. A modification of the relations between will, reason, and authority (the very function that constitutes Enlightenment) always elicits a counter-reaction to this renegotiation. This counter-reaction in turn is grounded in the faulty assumption that to attempt any renegotiation of the complex triadic relation of reason, will, and authority leads only to madness. This is a persistent fear passed down through generations; it is a transgenerational dementophobia.

What Ferraris helps make clear is that Jacobi's dilemma remains our own. His fear of madness has persisted through generations even if his name has somewhat faded. Jacobi's fear that Spinozism and transcendental idealism lead to nihilism has been transmuted into the New Realist's fear that postmodernism has yielded a similar brand of nihilism, in which subjectivity is conflated with divinity. Put otherwise, for both Jacobi and Ferraris the faulty inflation of the mind's determinative capacities has exiled any relevant determinative capacities of the world. The world no longer constitutes the structures of the mind and thought; instead it is the mind and thought that come to constitute the world in what Quentin Meillassoux characterizes as Kant's “Ptolemaic counter-revolution” (2008 [2006]: 118). The finite mind assumes itself to be capable of the divine powers of creation. We have seen the formal and substantive overlap between Jacobi's fideistic realism and Ferraris' New Realism. Both maintain that the only way to know the real is to assume a fundamental passivity in relation to the authority of an absolute externality. Both argue that only through a rationally inscrutable, anti-conceptual form of access (either "faith" or "experience") can we find meaning and truth. Meaning and truth are absolutely received and this reifies the absolute division between subject and object. The problem here 
is not the idea of passive reception or external constraint as such; the problem is instead the absolutization of passivity that forestalls the functioning of reason. ${ }^{19}$

I want to conclude by insisting that this analysis is not to be taken as a criticism of the return to realism or even of the speculative realists more generally. In the end, I do believe Ferraris' error far overshadows his insight. What the contextualization of Ferraris' New Realism in the anti-Enlightenment tradition of Jacobi provides is a clarification of the realist insight and an indication of a path forward for speculative philosophy. Ferraris believes himself to be setting a high bar for New Realism in writing the following:

We should try instead a maximalist commitment, that could be called "speculative" (along the lines of Anglo-French speculative realism) because it shares the ambition of the great speculative systems of the idealistic age: that is, to philosophically account for the integration between science and commonsense. (Ferraris 2015b: 35)

This aspiration is ultimately modest, and disappointingly so. The reconciliation of science and common sense in speculative philosophy is a consequence of a much broader philosophical aspiration. Meillassoux exposes the core of speculative realism when he argues for an expansion of the reaches of thought in order to face the task of once again renegotiating the relation between philosophical rationality and the authority of the real. In fact, the entire purpose of the controversial argument of the arche-fossil and ancestrality is to enjoin us "to reconcile thought and the absolute" (Meillassoux 2008 [2006]: 128). This is precisely the task undertaken by Hegel and Schelling, and it is one that must be remembered and worked through instead of denigrated and cast aside. In other words, we must recognize New Realism's hasty "goodbye" to Kant as necessitating a "hello" to post-Kantian idealism and the beckoning of the Absolute.

\section{References}

Bayle, Pierre (1991). Historical and Critical Dictionary: Selections [1740]. Trans. Richard H. Popkin. Indianapolis/Cambridge: Hackett Publishing Company.

Beiser, Freidrich C. (1993). The Fate of Reason: German Philosophy from Kant to Fichte.

Cambridge, MA: Harvard University Press.

${ }^{19}$ Reza Negarestani's Intelligence and Spirit is an artful investigation of this phenomenon. "Intelligence only turns into intelligence when it loses its passivity, when it actively begins to render reality intelligible and, in doing so, begins to re-engineer the reality of itself" (Negarestani 2019: 29). I have argued for this in more detail elsewhere (Norris 2019). 
Bernstein, Jay M (2017). “Remembering Isaac: On the Impossibility and Immorality of Faith.” In The Insistence of Art: Aesthetic Philosophy After Early Modernity, ed. Paul A. Kottman, 257-58. New York: Fordham University Press.

Boehm, Omri (2014). Kant's Critique of Spinoza. Oxford: Oxford University Press.

Della Rocca, Michael (2008). Spinoza. London: Routledge.

Ferraris, Maurizio. (2013) Goodbye Kant! What Remains of the Critique of Pure Reason [2004]. Trans. Richard Davies. Albany, NY: State University of New York Press.

Ferraris, Maurizio (2014). Manifesto of New Realism [2012]. Trans. Sarah De Sanctis. Albany, NY: State University of New York Press.

Ferraris, Maurizio (2015a). Introduction to New Realism. Trans. Sarah De Sanctis. London: Bloomsbury.

Ferraris, Maurizio (2015b). Positive Realism. Winchester: Zero Books.

Gabriel, Markus (2015). Fields of Sense: A New Realist Ontology. Edinburgh: Edinburgh University Press.

Grier, Michelle (2001). Kant's Doctrine of Transcendental Illusion. Cambridge: Cambridge University Press.

Foucault, Michel (1984). “What is Enlightenment?” In The Foucault Reader, ed. Paul Rabinow, trans. Catherine Porter, 32-50. New York: Pantheon Books.

Jacobi, Friedrich Heinrich (1994). The Main Philosophical Writings and the Novel Allwill. Trans. George Di Giovanni. Montreal: McGill-Queen's University Press.

Jacobi, Friedrich Heinrich (1994). "Concerning the Doctrine of Spinoza in Letters to Herr Moses Mendelssohn" [1785]. In The Main Philosophical Writings and the Novel Allwill. Trans. George Di Giovanni, 173-252. Montreal: McGill-Queen's University Press.

Jacobi, Friedrich Heinrich (1994). "David Hume on Faith, or Idealism and Realism, A Dialouge" [1787] In The Main Philosophical Writings and the Novel Allwill. Trans. George Di Giovanni, 253-338. Montreal: McGill-Queen's University Press.

Jacobi, Friedrich Heinrich (1994). "Concerning the Doctrine of Spinoza in Letters to Moses Mendelssohn” [1789]. In The Main Philosophical Writings and the Novel Allwill. Trans. George Di Giovanni, 339-78. Montreal: McGill-Queen’s University Press.

Jacobi, Friedrich Heinrich (1994). “Jacobi to Fichte.” [1799] In The Main Philosophical Writings and the Novel Allwill. Trans. George Di Giovanni, 497-536. Montreal: McGill-Queen's University Press.

Janssens, David (2003). "The Problem of Enlightenment: Strauss, Jacobi, and the Pantheism Controversy.” The Review of Metaphysics 56.3: 605-31.

Johnston, Adrian (2008). Žižek's Ontology: A Transcendental Materialist Theory of Subjectivity. Evanston, IL: Northwestern University Press.

Johnston, Adrian (2019). Prolegomena to Any Future Materialism: Volume Two, A Weak Nature Alone. Evanston, IL: Northwestern University Press.

Hegel, Georg Wilhelm Friedrich (1977). The Difference Between Fichte's and Schelling's System of Philosophy [1801]. Trans. H.S. Harris and Walter Cerf. Albany, NY: State University of New York Press.

Kant, Immanuel (2003). Critique of Pure Reason [1787]. Trans. Norman Kemp Smith. New York: Palgrave Macmillan.

McDowell, John (1996). Mind and World. Cambridge, MA: Harvard University Press. Meillassoux, Quentin (2008). After Finitude: An Essay on the Necessity of Contingency [2006]. Trans. Ray Brassier. London: Continuum.

Milbank, John (1999). “The Theological Critique of Philosophy in Hamann and Jacobi.” In Radical Orthodoxy: A New Theology, ed. John Milbank, Catherine Pickstock, and Graham Ward, 21-37. London: Routledge.

Mullarkey, John (2006). Post-Continental Philosophy: An Outline. London: Continuum. Norris, Benjamin (2015). "Review of Markus Gabriel's Fields of Sense: A New Realist 


\section{Benjamin Norris}

Ontology.” The Graduate Faculty Philosophy Journal 36.2: 493-96.

Norris, Benjamin (2019). "The Education of Kanzi and the Notion of Progress:

Reza Negarestani's Intelligence and Spirit.” Pli 30: 164-90.

Negarestani, Reza (2019). Intelligence and Spirit. Falmouth: Urbanomic.

Sellars, Wilfrid (1968). Science and Metaphysics: Variations on Kantian Themes. London: Routledge.

Žižek, Slavoj (1993). Tarrying with the Negative: Kant, Hegel, and the Critique of Ideology. Durham, NC: Duke University Press. 